\title{
The Effect of Chronical Intake of Arsenic on the Liver Tissue Respiration in Mice
}

In the course of our experiments on some hygienic aspects of long-termed intake of arsenic, it was noted that a chronic application of even small doses of this toxic agent in drinking water produced in mice significant histological changes of the liver ${ }^{1}$. It was therefore of interest to study whether this effect was connected with respiratory changes of the liver tissue. This topic was studied in vitro in rat liver and kidney slices ${ }^{2}$ and in mitochondria ${ }^{3-5}$; but we could not find any paper dealing with the influence of arsenic administered in vivo. The aim of the present study was to find whether, and to what degree, tissue respiration can be influenced by a chronic intake of arsenic in drinking water.

The experiments were done with hairless mice used throughout all our studies of arsenic action. Arsenic was applicated as trioxide in the drinking water in concentrations of 5 and $50 \mathrm{mg} / 1$ respectively. These solutions were given ad libitum. After 256 days the mice were decapitated, the liver was rapidly removed and homogenized in icecold sucrose solution $(0.25 M)$. Oxygen consumption in the homogenate was measured by the conventional Warburg technique on air and related to the dry weight of the homogenate.

In another set of experiments, arsenic trioxide was added to the assay system in the final concentration of $10^{-3} M$. The scope of these experiments was to find whether a chronic administration of arsenic contributes to activation of adaptative mechanisms.

The results are summarized in the Table. It can be seen that arsenic markedly suppresses the oxygen consumption of the liver tissue. However, the difference between the

The oxygen consumption in liver homogenates of mice exposed to arsenic

\begin{tabular}{lll}
\hline $\begin{array}{l}\text { Concentration of } \\
\text { arsenic in drinking } \\
\text { water }\end{array}$ & $\begin{array}{l}\text { No arsenic added } \\
\mu 1 \mathrm{O}_{2} / \mathrm{h} / \mathrm{mg} \\
\text { dry weight }\end{array}$ & $\begin{array}{l}\text { Arsenic added } \\
\mu \mathrm{l} \mathrm{O}_{2} / \mathrm{h} / \mathrm{mg} \\
\text { dry weight }\end{array}$ \\
\hline None & $4.88 \pm 0.52^{\mathrm{a}}(6)$ & $2.89 \pm 0.18 \quad(5)$ \\
$5 \mathrm{mg} / 1$ & $2.99 \pm 0.51^{\mathrm{b}}(4)$ & $2.46 \pm 0.30 \quad(6)$ \\
$50 \mathrm{mg} / \mathrm{l}$ & $2.59 \pm 0.12^{\mathrm{b}}(4)$ & $1.88 \pm 0.16^{\mathrm{b}}(5)$
\end{tabular}

a Mean \pm standard error of the mean. ${ }^{b}$ Value significantly different from control. No. of animals in brackets. groups is not proportional to the differences in concentrations and it is also not statistically significant.

The presence of arsenic in the incubation medium caused a significant decrease of the respiration in normal mice. On the other hand, in animals exposed to the lower concentration of arsenic, only slight and insignificant decrease of oxygen consumption could be observed. Even in the group drinking $50 \mathrm{mg}$ arsenic/l the decrease was much lower than in the experiment without in vitro addition of arsenic. The lower sensitivity to arsenic may be due probably to an adaptation of the organism to a prolonged exposure to low doses of the toxic agent, or to a decreased level of oxidizable substrates. The first presumption seems to be supported by our finding of a decrease in acute toxicity of arsenic during its chronic intake ${ }^{6}$.

In addition, the present study shows that the method used can be a valuable and sensitive indicator of arsenic intoxication which registers even small changes not detectable with current methods.

Zusammenfassung. Es wird gezeigt, dass eine langfristige Zufuhr von Arsen in Trinkwasser bei Mäusen eine wesentliche Abnahme des Sauerstoffverbrauches des Leberhomogenates hervorruft. Die chronische Verabreichung von niedrigen Arsengaben blockiert die respirationshemmende Wirkung von Arsen in vitro, was wahrscheinlich auf eine Adaptation des Organismus zurückzuführen ist.

V. BENCKo and Z. ŠIMÁNĚ

Institute of Hygiene and Department of Pharmacology, Charles University Medical School of Hygiene, Praha (Czechoslovakia), 29 January 1968.

1 V. BENCKo, K. NeJEDLÝ and J. Somora, Čslká Hyg., in press.

2 W. Huges, Biochem. J. 41, 8 (1947).

8 M. J. Flechtner, A. L. Fluharthy and D. R. Sanady, Biochim. biophys. Acta 60, 425 (1962).

4 M. J. Flechtner and D. R. Sanady, Archs Biochem. Biophys. $96,139(1962)$.

5 A. L. Fluharthy and D. R. Sanady, Biochemistry 1, 276 (1962).

- V. Bencko and K. Symon, J. Hyg. Epidem. Microbiol. Immun., in press.

\section{Adrenergic Fibres in the Mucous Membrane of Guinea-Pig Alimentary Tract}

A rich nerve supply to the mucous membrane of the small intestine was recognized by DOGIEL $^{1}$ and by $\mathrm{CAJAL}^{2}$ ('plexus periglandulaire' and 'plexus des villosités'); according to the latter author, these fibres are motor nerve fibres, being intimately related to smooth muscle cells and to secretory cells. By electron microscopy, Honjin et al. ${ }^{3}$ have observed bundles of nerve fibres in the muscularis mucosae of tunica propria of human small intestine: these fibres contain agranular vesicles and are situated in close contact with CAJAL's interstitial cells. Silva described nerve fibres around mouse colon glands, running in bundles and containing both granular and agranular vesicles. By fluorescent microscopy, in cat and monkey small intestine, JACOBOwITZ ${ }^{5}$ has followed adrenergic fibres as far as the tunica propria, where they branch over the basal aspect of the glandular epithelium.

By employing the FALCK and Hillarp method ${ }^{6}$ for the histochemical detection of biogenic amines, we have investigated the distribution of adrenergic nerve fibres in the mucosa of different segments of the digestive tract. The stomach, the ileum and the rectum of 6-to 8-monthold guinea-pigs have been the object of the present 